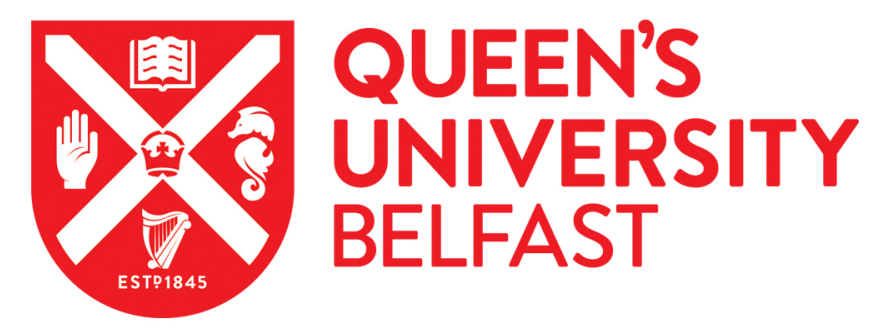

\title{
Stable isotope analysis: Outline of methodology and a review of studies in Siberia and the Eurasian steppe
}

Svyatko, S. V. (2016). Stable isotope analysis: Outline of methodology and a review of studies in Siberia and the Eurasian steppe. Archaeology, Ethnology and Anthropology of Eurasia, 44(2), 47-55.

https://doi.org/10.17746/1563-0110.2016.44.2.047-055

Published in:

Archaeology, Ethnology and Anthropology of Eurasia

Document Version:

Publisher's PDF, also known as Version of record

Queen's University Belfast - Research Portal:

Link to publication record in Queen's University Belfast Research Portal

\section{Publisher rights}

Copyright 2016 the authors.

This is an open access article published under a Creative Commons Attribution License (https://creativecommons.org/licenses/by/4.0/), which permits unrestricted use, distribution and reproduction in any medium, provided the author and source are cited.

\section{General rights}

Copyright for the publications made accessible via the Queen's University Belfast Research Portal is retained by the author(s) and / or other copyright owners and it is a condition of accessing these publications that users recognise and abide by the legal requirements associated with these rights.

Take down policy

The Research Portal is Queen's institutional repository that provides access to Queen's research output. Every effort has been made to ensure that content in the Research Portal does not infringe any person's rights, or applicable UK laws. If you discover content in the Research Portal that you believe breaches copyright or violates any law, please contact openaccess@qub.ac.uk. 


\author{
S.V. Svyatko \\ ${ }^{14}$ CHRONO Centre for Climate, the Environment, and Chronology, \\ Queen's University of Belfast, \\ Belfast, BT7 1NN, Northern Ireland, United Kingdom \\ E-mail: s.svyatko@qub.ac.uk
}

\title{
Stable Isotope Analysis: Outline of Methodology and a Review of Studies in Siberia and the Eurasian Steppe
}

Stable carbon and nitrogen isotope analysis is one of the main techniques for assessing various aspects of life of prehistoric populations, including diet and economy. Here we present the theoretical basics of the method, and a review of the major stable-isotope paleodietary studies in Siberia and the Eurasian steppe by the end of 2013. Existing data show that the diet of various Chalcolithic to Early Iron Age populations in the region varied in time and space, and included substantial amounts of fish. Variations in diet and economy between groups of the same archaeological cultures were likely related to adaptations to local environments and climates. Millet appeared in the region (in the Minusinsk Basin) only in the 14th century BC. Thus Southern Siberia apparently became one of the first centers of millet cultivation in the entirety of Siberia. The impact of climate - particularly precipitation-on the isotopic values of humans has also been recorded. Despite the existence of a number of studies in Siberia and the Eurasian steppe, paleodietary research using stable-isotope analysis in the region is still at the data acquisition stage. One of the main criteria of modern research in the region is a systematic and well-designed approach to the isotopic analysis of various archaeological populations. This research must include not only human bone samples, but also all potential dietary components, such as terrestrial and aquatic animals, and associated plants.

Keywords: Stable-isotope analysis, Eurasian steppe, Siberia, paleodiet.

\section{Introduction}

Isotope analysis is one of the most productive modern techniques for the investigation of various aspects of life in ancient populations, such as diet and migrations. Carbon $\left(\delta^{13} \mathrm{C}\right)$ stable isotope analysis is used to estimate the proportions of so called $\mathrm{C}_{3}$ versus $\mathrm{C}_{4}$ plants and to distinguish between the consumption of marine versus terrestrial organisms in an individual's diet; and it is often used in conjunction with nitrogen stable isotope $\left(\delta^{15} \mathrm{~N}\right)$ analysis, which identifies the trophic level (position in a food chain) of an individual. Hydrogen isotope ratios $(\delta \mathrm{D})$ of bone collagen can also demonstrate a trophic level effect (Reynard, Hedges, 2008). The sulfur $\left(\delta^{34} \mathrm{~S}\right)$, lead $\left({ }^{208} \mathrm{~Pb} /{ }^{206} \mathrm{~Pb}\right.$ and $\left.{ }^{207} \mathrm{~Pb} /{ }^{206} \mathrm{~Pb}\right)$, strontium $\left({ }^{87} \mathrm{Sr} /{ }^{86} \mathrm{Sr}\right)$, and oxygen $\left(\delta^{18} \mathrm{O}\right)$ isotope values reflect the geographical origin of an individual, as these are characteristic of particular regions. Analysis of sulfur isotopes has also been employed in studies of estuarine food webs where there is a pronounced difference between the isotopic composition of primary sulfur-sources-for example, between marine, freshwater, and terrestrial sulfate (Richards, Fuller, Sponheimer et al., 2003; Privat, O'Connell, Hedges, 2007).

This work focuses on carbon and nitrogen stable isotope analysis of bone collagen. This technique allows

Archaeology, Ethnology \& Anthropology of Eurasia 44/2 (2016) 47-55 Email: Eurasia@archaeology.nsc.ru (C) 2016 Siberian Branch of the Russian Academy of Sciences

(C) 2016 Institute of Archaeology and Ethnography of the Siberian Branch of the Russian Academy of Sciences (c) 2016 S.V. Svyatko 
dietary measurements at individual level, and the analysis of a group of people can demonstrate dietary variations within a population (between people of different sexes, age groups, and social status).

\section{Theoretical framework of the method}

Use of carbon isotopes. Carbon occurs in the atmosphere in two stable isotopes, ${ }^{12} \mathrm{C}$ and ${ }^{13} \mathrm{C}$. Isotopic ratio of ${ }^{13} \mathrm{C} /{ }^{12} \mathrm{C}$ is expressed in delta $(\delta)$ values per mil $(\%)$, relative to the international standard of PDB (a marine fossil Belemnitella from the Pee Dee geological formation in South Carolina). In the process of photosynthesis, carbon atoms are incorporated into plants in the form of $\mathrm{CO}_{2}$, and then transferred further up the food chain. There are several types of photosynthetic pathways. Most plants use the $\mathrm{C}_{3}$ photosynthetic pathway, which incorporates atmospheric $\mathrm{CO}_{2}$ into a three-carbon molecule in plant tissue; but some use the $\mathrm{C}_{4}$ photosynthetic pathway, which generates a molecule containing four carbon atoms. The latter group is represented by approximately ten plant families; and includes, in particular, maize, cane sugar, certain millets, chenopods, sorghums, and amaranths. The Crassulacean acid metabolism (CAM) group of plants, represented by tropical succulents, also exists; but these plants only rarely form part of the diets of herbivores or humans. $\mathrm{C}_{3}$ plants are well adapted to temperate climates, their $\delta^{13} \mathrm{C}$ values average about $-26.5 \%$. $\mathrm{C}_{4}$ plants are better adapted to arid climates and their $\delta^{13} \mathrm{C}$ average about $-12.5 \%$ (Chisholm, 1989; Tieszen, Fagre, 1993).

A fractionation difference of around 4-5\%o occurs between the $\delta^{13} \mathrm{C}$ values of plant food and the bone collagen of its consumer. This is the "collagen enrichment factor" and is caused by the metabolic processes of the consumer (Ambrose, 1993). Thus, the bone collagen $\delta^{13} \mathrm{C}$ value from herbivores that subsist only on $\mathrm{C}_{3}$ grasses would be ca $-21.5 \%$. If the diet were based only on $\mathrm{C}_{4}$ grasses, $\delta^{13} \mathrm{C}$ would be ca $-7.5 \%$. If an individual consumes both $\mathrm{C}_{3}$ and $\mathrm{C}_{4}$ species, the $\delta^{13} \mathrm{C}$ value for its collagen will lie somewhere between -21.5 and $-7.5 \%$, and ideally the proportions of $\mathrm{C}_{3}$ and $\mathrm{C}_{4}$ plants in its diet could be estimated.

A small (approximately 0.5-2\%) enrichment for isotopic values of carbon occurs in each step of a food chain: if the $\delta^{13} \mathrm{C}$ value of bone collagen of a herbivore subsisting on $\mathrm{C}_{3}$ plants provides a value of ca $-21.5 \%$, then the collagen of a human consuming the meat of that herbivore will give a $\delta^{13} \mathrm{C}$ value of ca $-20.5 \%$ (Schoeninger, 1985; Bocherens, Drucker, 2003). Therefore, carbon isotopic ratios may be enriched in weaning infant mammals, owing to the trophic level increase as a result of consuming maternal milk (Jenkins et al., 2001).
The $\delta^{13} \mathrm{C}$ values in marine ecosystems usually lie in an intermediate position between the values of terrestrial $\mathrm{C}_{3}$ and $\mathrm{C}_{4}$, depending on their carbon sources. Freshwater aquatic food-webs appear to have more depleted $\mathrm{C}_{3}$-like carbon isotopic compositions (Ambrose, 1993). Therefore, freshwater fish appears to be more problematic to detect in paleodietary reconstructions, as compared to marine fish. As both the consumption of $\mathrm{C}_{4}$ plants and marine food can result in increased $\delta^{13} \mathrm{C}$ values of bone collagen, it can be difficult to distinguish between the two dietary components when the analysis is restricted to only carbon stable isotopes. However, an examination of stable isotopes of both carbon and nitrogen can address this issue, as nitrogen stable isotope analysis enables the determination of the trophic level of a consumer.

Several non-dietary factors may also affect the carbon isotopic ratios of an adult individual. In particular, the canopy effect in forests results in more negative $\delta^{13} \mathrm{C}$ of leaves nearest the ground, in the shade, in comparison with those at the top of canopy (van der Merwe, Medina, 1991). This effect extends on to the food chain, to forest and aquatic fauna, and thus will apparently have an effect on $\delta^{13} \mathrm{C}$ values of humans consuming fauna from different areas.

Use of nitrogen isotopes. Nitrogen is represented by two stable isotopes, ${ }^{14} \mathrm{~N}$ and ${ }^{15} \mathrm{~N}$. Their isotopic ratio $\left(\delta^{15} \mathrm{~N}\right)$ is expressed per mil $(\%)$ relative to the international standard of atmospheric nitrogen (i.e. Ambient Inhalable Reservoir, or AIR). Nitrogen penetrates into most plants from soil as a result of bacterial degradation; the $\delta^{15} \mathrm{~N}$ values of most modern plants vary between 0 and $5 \%$. The consumer collagen usually displays $\delta^{15} \mathrm{~N}$ ratios, which are about 3-6\% greater than its diet (Hedges, Reynard, 2007; O'Connell et al., 2012). Therefore, the nitrogen isotopic values of populations that rely on terrestrial herbivore animal protein in their diet would average around $9 \%$, although this depends on the starting nitrogen isotopic values of local plants. The nitrogen levels of a consumer will further increase when relying on aquatic resources, owing to the more complicated structure of the food-web (e.g. a larger number of trophic levels) in water ecosystems.

Past research has suggested several non-dietary factors which may influence the nitrogen isotopic ratios of an adult individual.

Nursing effect. Pre-weaned infants less than two years of age are commonly enriched with nitrogen by around $2-3 \%$, as compared to weaned infants and older individuals: the feeding child is a level higher in the food-chain than its mother. For this reason, young individuals are usually excluded from stable-isotope studies, as their high $\delta^{15} \mathrm{~N}$ levels can confuse the dietary interpretations. Since most of an individual's teeth are formed during infancy, dentine and enamel are also 
subject to the nursing effect. However, the isotopic analysis of dentine is widely used for determining the weaning age (see, e.g., (Clayton, Sealy, Pfeiffer, 2006)).

Climatic effect. $\delta^{15} \mathrm{~N}$ ratios in humans and animals may be higher in arid, savannah or desert environments (see, e.g., (Murphy, Bowman, 2006)).

Manuring effect. Manuring increases $\delta^{15} \mathrm{~N}$ ratios of soil and, consequently, the ratios of plants raised in manured soil (Bogaard et al., 2007, 2013). One can suggest that continuous use of nitrogen-enriched plants in the diet would increase the $\delta^{15} \mathrm{~N}$ ratios of the bone collagen of a consumer, which could be erroneously interpreted as a result of consumption of animal protein.

Limitations of carbon and nitrogen stable isotope techniques. Bone collagen is the main material used for carbon and nitrogen stable isotope analysis. Collagen is absorbed primarily from the protein component of the diet, and therefore it reflects mainly the protein sources of the individual's diet (Chisholm, 1989). Bone, including its collagen component, is constantly being repaired. According to different data, the turnover rate of bonecollagen varies between two and 30 years, depending on the particular part of the skeleton (Ibid.; Wild et al., 2000). For example, it has been demonstrated that the collagen turnover-rate in a human femur is more than ten years (Hedges et al., 2007). In trabecular bone, the turnover is quicker than in the cortical part of bone (Parfitt, 1994; Manolagas, 2000). Thus, isotopic data reflect not the average diet of the individual's entire life, but rather the diet of the last decade before death. Comparison of the results from collagen and dentin enables identification of an individual's dietary changes or migrations throughout his life.

\section{Bone-sampling and pretreatment of osteological materials}

Stable isotope analysis requires several grams of compact, solid bone (brittleness of bone often indicates that its collagen has degraded). Ideally, samples from a group of individuals should originate from the same part of each skeleton. As mentioned above, depending on the nature of the study, tooth-dentin should be treated with caution. Obviously, bones with traces of contaminants (glue, ink) should not be sampled.

In most laboratories, pretreatment of the bone sample for the analysis (collagen extraction) is carried out using an improved method (Brown et al., 1988), with an additional ultrafiltration step (Bronk Ramsey et al., 2004), and includes bone demineralization, protein gelatinization, filtration and ultrafiltration of gelatin (for removing the smallest impurities), and subsequent freezedrying. The isotopic composition of the resulting dry collagen is analyzed using a mass spectrometer.

\section{Quality assessment for well-preserved bone gelatin}

1. Bone collagen content of at least $0.5 \%$ (van Klinken, 1999).

2. Carbon to nitrogen atomic ratio of collagen $\left(\mathrm{C}: \mathrm{N}_{\mathrm{at}}\right)$ within 2.9-3.5 (DeNiro, 1985; Bronk Ramsey et al., 2004). $\mathrm{C}: \mathrm{N}_{\mathrm{at}}$ is calculated according to the following formula: $\mathrm{C}: \mathrm{N}_{\mathrm{at}}=\frac{\% \mathrm{C}}{\% \mathrm{~N}} \times \frac{14}{12}$, where $\% \mathrm{C}$ and $\% \mathrm{~N}$ represent carbon and nitrogen content in collagen.

3. As an additional criterion, the individual contents of carbon and nitrogen in collagen can be used. $\% \mathrm{C}=$ $=34.8 \pm 8.7(1 \sigma) \mathrm{wt}$ and $\% \mathrm{~N}=11 \div 16 \mathrm{wt}$ are characteristics of well-preserved collagen (van Klinken, 1999). Higher $\% \mathrm{C}$ ratios might indicate admixture of organic carbon, while lower ratios indicate the admixture of inorganic substances.

When publishing the results, in addition to the laboratory ID and isotopic results, the collagen content/ yield of the sample, $\mathrm{C}: \mathrm{N}_{\mathrm{at}}$, skeletal part analyzed, and also the species, sex, and age of the individual and details of the burial (site, grave/skeleton number) should be specified.

\section{Review of studies in Siberia and the Eurasian Steppe}

To date, a substantial number of paleodietary studies using stable isotope analysis has been undertaken throughout the world, in particular with regard to the economy of ancient populations in the transitional periods between various archaeological epochs (Richards, Schulting, Hedges, 2003), and the spread of cereals in Asia (Pechenkina et al., 2005; Hu et al., 2008) and America (Schoeninger, 2009). This section brings together examples of the most relevant work carried out in the Eurasian Steppe (Fig. 1). The modern isotopic background (analysis of plants) for the region has been presented in series of works (Makarewicz, Tuross, 2006; Makarewicz, 2014; Wang, 2004, 2005; Wang et al., 2005; Pyankov et al., 2000; and others).

Northern China. As documented archaeologically, millet-cultivation has been practiced in Northern China since $6500 \mathrm{BC}$, and by $5000 \mathrm{BC}$ millet-remains are found in nearly every site of the region. However, the isotopic analysis of the Early Neolithic individuals from the Henan Province (site of Jiahu, 7000$5800 \mathrm{BC}$ ) suggests for this population a primarily $\mathrm{C}_{3}$-based diet that included a substantial proportion of animal protein. Further stable-isotope analysis of humans from the Xiaojingshan site $(6000 \mathrm{BC})$ showed that millet contributed approximately $25 \%$ of dietary protein, with the rest coming from $\mathrm{C}_{3}$-based plant and animal sources (Hu et al., 2008). 
Interesting results were obtained for humans from the Xinglongwa site (6200-5400 BC) in Inner Mongolia (Ibid.). Despite the high $\delta^{13} \mathrm{C}$ and $\delta^{15} \mathrm{~N}$ values of humans $\left(\delta^{13} \mathrm{C}_{\text {mean }}=-8.9 \% ; \delta^{15} \mathrm{~N}_{\text {mean }}=9.6 \%\right)$, soil flotation showed very little evidence of millet-grains; however, pollen analysis and plant-seed recovery performed in the area nearby revealed that a large number of $\mathrm{C}_{4}$ species dominated the grassland. Apparently, high $\delta^{13} \mathrm{C}$ values in human collagen came from the consumption of $\mathrm{C}_{4}$-derived animal protein, rather than from the direct consumption of millet.

Stable-isotope evidence from Middle-to-Late Neolithic humans and animals from Northern China indicates subsistence strategies different from those of Early Neolithic populations. Human samples from Jiangzhai and Shijia (4900-4000 BC) suggest that millet constituted $75-85 \%$ of their diet. Pig and dog samples from Xipo and Kangjia sites (4000-3500 and 2500$2000 \mathrm{BC}$ respectively) indicate consumption of substantial amounts of $\mathrm{C}_{4}$ plants (presumably millets) by those animals. Apparently, millet was used as a fodder for the animals (Pechenkina et al., 2005). However, it is quite possible that pigs and dogs just scavenged human refuse for food.

Southern Trans-Urals. A variety of domestic animal remains, as well as burnt food residues from the interior of the pottery vessels found in the Bolshekaragansky cemetery (the necropolis of the settlement of Arkaim, Sintashta culture, 18th-16th centuries BC) suggest that meat, dairy, and plant (including cereal) meals formed the basis of the human diet. However, the results of the isotopic analysis of humans and animals from kurgan 25 of Bolshekaragansky cemetery and from Kamennyi Ambar-5 site indicate that people consumed a large amount of animal protein, and were not dependent upon plants as their primary source of nutrition (Privat, 2002).

Baraba forest-steppe. The archaeological finds from the Late Bronze-Iron Age site of Chicha-1 (14th century $\mathrm{BC}$ to 1 st century $\mathrm{AD}$ ), including bird- and fish-bones, suggest that stock-breeding, fishing, and hunting were the main sources of subsistence for the people. Systematic investigations of the site did not reveal any botanical remains which could be associated with agriculture. Isotopic analysis of humans, fish, and terrestrial fauna from Chicha-1 indicates that freshwater resources, primarily fish, formed the main protein source for the population, with further dietary input from domestic and wild terrestrial herbivores, mainly horse and elk (Privat et al., 2005).

Dnieper region. The analysis of humans and fauna from Mesolithic and Chalcolithic sites of the Dnieper Rapids region of Ukraine revealed that the diet of the populations throughout the period of 10000 $4500 \mathrm{cal} \mathrm{BC}$ was based mainly on $\mathrm{C}_{3}$ terrestrial resources and significant amount of river-fish (Lillie, Richards, 2000; Lillie, Jacobs, 2006; Lillie, Budd, Potekhina, 2011). The overall contribution of river-fish apparently increased during the Neolithic.

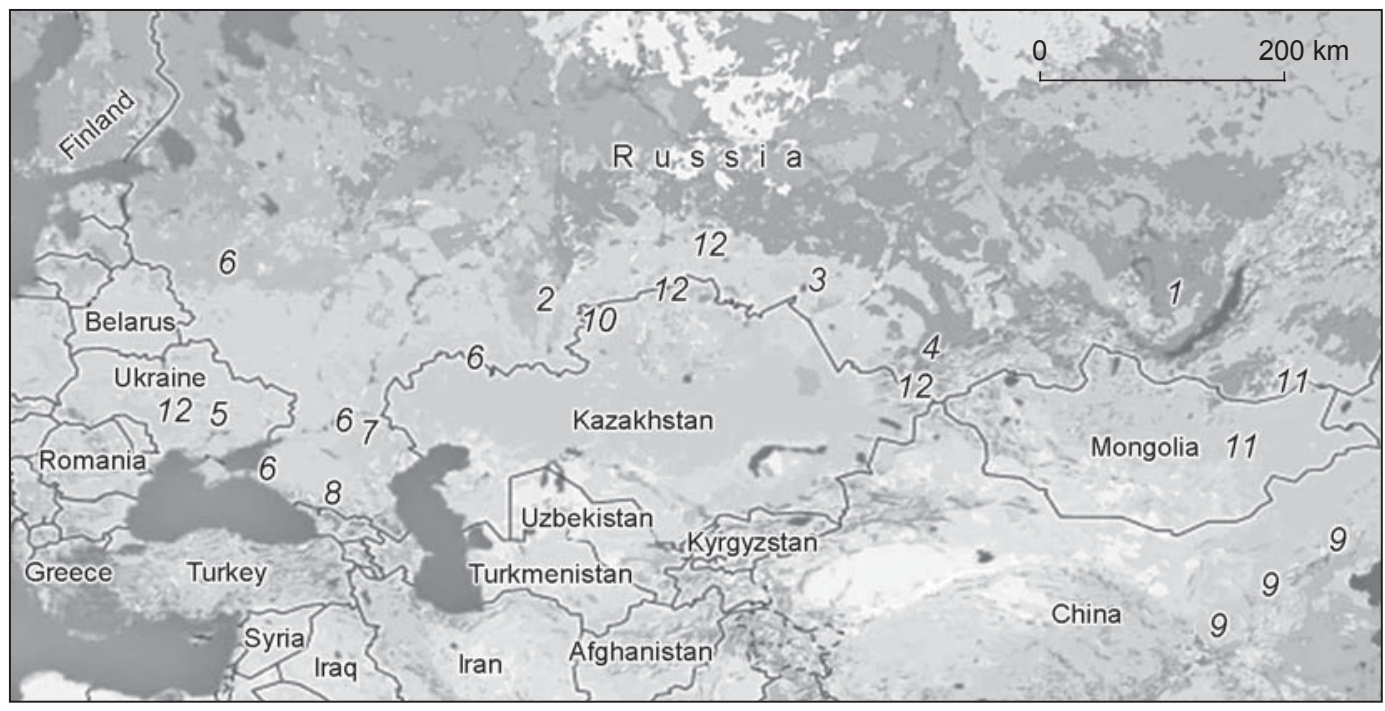

Fig. 1. Isotopic research in the Eurasian Steppe:

1 - Lake Baikal region (Katzenberg, Goriunova, Weber, 2009; Katzenberg et al., 2012; Katzenberg, Weber, 1999); 2 - Chelyabinsk Region (Privat, 2002); 3 - Baraba forest-steppe (Privat et al., 2005); 4 - Minusinsk Basin and Tuva (Murphy et al., 2013; Svyatko et al., 2013); 5 - Dnieper region (Lillie, Richards, 2000; Lillie, Budd, Potekhina, 2011); 6 - Volga-Don interfluve, middle Ural River, Novorossiysk and Moscow Regions (Iacumin et al., 2004); 7 - Northern Caspian region (Shishlina et al., 2007, 2009, 2012); 8 - North Caucasus (Hollund et al., 2010); 9 - Northern China (Hu, Ambrose, Wang, 2006; Hu et al., 2008; Pechenkina, Benfer, Zhijun, 2002; Pechenkina et al., 2005; Pechenkina, Benfer, Xiaolin, 2007); 10 - Northern Kazakhstan (Miller et al., 2014 ); 11 Mongolia (Fenner, Tumen, Khatanbaatar, 2014); 12 - sites of Botai (Kazakhstan), Krivoy Rog (Ukraine), Verkh-Kaldzhin-2 (the Altai Republic), and Abatsky-3 (SW Siberia) (O’Connell, Levine, Hedges, 2003). 
North Caucasus. Chalcolithic to Bronze Age materials from North Caucasus (Hollund et al., 2010) revealed a negative correlation between isotopic values of humans and fauna on the one hand, and geographical location of the sites on the other: the highest isotopic values were observed in individuals from arid steppeareas in the north of the region. Apparently, climatic fluctuations in the region resulted in isotopic variations in local fauna, and, subsequently, in humans. In general, high $\delta^{15} \mathrm{~N}$ ratios of people also suggest dietary reliance on aquatic sources.

The European part of Russia. The possible relation between the aridity of a region and the isotopic ratios of its inhabitants has also been observed by Iacumin et al. (2004). $C_{4}$ plants have been recorded in the steppe zone of the European part of Russia from at least the $3 \mathrm{rd}$ millennium $\mathrm{BC}$; however, there is no evidence for $\mathrm{C}_{4}$ plants in Moscow Region until at least the 3rd millennium BC, and in the Black Sea coast until at least the 4th millennium BC. The diet of the human populations of the steppe was mainly terrestrial-based, and included some proportion of fish. By contrast, the ancient Mesolithic and Neolithic populations who lived in the territory of modern Moscow Region apparently used large amounts of fish.

Northern Caspian region. The Bronze Age population of the Caspian steppes are characterized by particularly high $\delta^{15} \mathrm{~N}$ levels and a generally wide spread of both isotopic values (Shishlina et al., 2007, 2009, 2012). This is probably related to both dietary (a large proportion of aquatic foods - fish and shellfish) and climatic factors (increased $\delta^{15} \mathrm{~N}$ values in plants during arid periods).

Northern Kazakhstan. The archaeological data indicate that in the Middle and Late Bronze Age, significant changes occurred in the settlement patterns and mortuary practices of the region, which traditionally have been related to the transition from a semi-settled lifestyle (combining stock-rearing and agriculture) to more mobile forms of pastoralism. However, stable-isotope analysis of humans and fauna from the Bestamak and Lisakovsk sites (Middle and Late Bronze Age, respectively) demonstrated that the diet of the population did not undergo significant change (Miller et al., 2014). The diet of the populations was primarily based on $\mathrm{C}_{3}$ resources, including meat and dairy products, and a small portion of fish.

Lake Baikal. From the isotopic perspective, this region is outstanding, as local fauna demonstrate a highly variable range of both carbon and nitrogen values (Katzenberg, Goriunova, Weber, 2009; Katzenberg et al., 2012; Katzenberg, Weber, 1999). Freshwater fish are highly variable in the $\delta^{13} \mathrm{C}$ values ranging from $-24.6 \%$ for the pelagic omul to $-12.9 \%$ for littoral species such as ide. Nitrogen isotopic values for the freshwater seals average $14 \pm 1.1 \%$, whereas terrestrial herbivores have much lower $\delta^{15} \mathrm{~N}$ values, ranging from 4 to $5 \%$ for deer and elk. These data demonstrate that considerable variation in the carbon stable isotope values of various animal species can occur even in inland freshwater ecosystems.

Isotopic variations in the prehistoric humans were primarily related to the proximity of the sites to the Lake: people who lived close to the Lake had the highest $\delta^{13} \mathrm{C}$ and $\delta^{15} \mathrm{~N}$ values for collagen, suggesting their reliance on the fish and seals from the Lake. People who lived further down the Angara River and along the upper Lena River had lower $\delta^{13} \mathrm{C}$ and $\delta^{15} \mathrm{~N}$ values, and apparently relied mainly on terrestrial herbivores and riverine fish as their protein source.

Mongolia. The appearance of the Mongol Empire in the 13th century significantly affected the lifestyle of both conquered populations and the conquerors. To assess the influence on its own population of the emergence of the Empire, isotopic analyses of the elite cemetery of Tavan Tolgoi, the less elite cemetery of Tsagaan chuluut, Bronze Age necropolis of Ulaanzuukh, and post-Empire human remains from Eastern Mongolia have been conducted (Fenner, Tumen, Khatanbaatar, 2014; Turner et al., 2012). In general, the results reveal $C_{3}$-food chains for the populations. $\delta^{15} \mathrm{~N}$ values of individuals from Tavan Tolgoi are significantly higher than those from Tsagaan chuluut and Ulaanzuukh. This was apparently related to either more animal protein in the diet of the elite strata, or to varying isotopic backgrounds for the three regions. No other differences in the diet of the elite and common people, nor in that of local Bronze Age pastoralists, have been identified.

Southern Siberia. Several isotopic studies have been performed in Southern Siberia (Murphy et al., 2013; Svyatko et al., 2013). Analysis of ca 280 human and animal bones from approximately 40 sites of five Chalcolithic to Early Iron Age archaeological cultures of the Minusinsk Basin (Svyatko et al., 2013) allowed a number of conclusions to be drawn:

- the diet of all the populations included fish;

- regional variations in the diets of different groups of the same culture have been observed, which apparently reflects the adaptation of people to the local landscapes and climates; and

- by the 14th century BC, millet (apparently brought from Northern China) spread in the Minusinsk Basin. This datum is consistent with the archaeological evidence for extensive contacts between the Karasuk and Tagar populations and China at the end of the Bronze Age and the beginning of the Early Iron Age. Apparently, Southern Siberia became one of the first centers for the spread of millet in Siberia in general. However, the exact time of the appearance of millet still needs to be specified, taking into account the possible existence of freshwater reservoir effects in the region. 
Conclusions. At the moment, stable-isotope paleodietary studies in Siberia and the Eurasian Steppe are at the data acquisition stage. Many regions, populations and phenomena still remain unexplored (e.g., the impact of climate-change on the isotope values of humans and animals, spread of millet in the region, the role of fish consumption and manuring in different cultures, etc.).

In general, the diet of the populations of various archaeological cultures in Siberia and the Eurasian Steppe varied in time and space (Fig. 2). The latter was apparently related to the attempts of people (even within the same culture) to adapt to specific environmental conditions.

The majority of the inland Neolithic-Bronze Age cultures (with the exception of the population from the Lake Baikal region) demonstrate low $\delta^{13} \mathrm{C}$ values (below $-18 \%$ ) and relatively high $\delta^{15} \mathrm{~N}$ levels, which is characteristic of the populations of temperate latitudes with an only partially producing economy (employing hunting, fishing and gathering together with stockbreeding). High $\delta^{15} \mathrm{~N}$ ratios (more than one trophic level high as compared to terrestrial fauna) indicate the important role of fish in the diet of the populations, despite the common scarcity of archaeological evidence for fishing. A strong marine influence (elevated levels of both $\delta^{15} \mathrm{~N}$ and $\delta^{13} \mathrm{C}$ ) has been recorded for the cultures of the Caspian steppes, as well as for the Early Iron Age population of the Black Sea's northern coast. Another food strategy was followed by the prehistoric population of Northern China: low $\delta^{15} \mathrm{~N}$ levels indicate consumption of primarily terrestrial foods.

Elevated $\delta^{13} \mathrm{C}$ values, suggesting consumption of millet, have been observed in populations of Northern China from the 6th millennium $\mathrm{BC}$, and in the population of the Minusinsk Depression since the 14th century BC. The increase in $\delta^{13} \mathrm{C}$ levels of the Early Iron Age population of Southern Urals and the Bronze Age to Medieval population of Mongolia is probably related to the aridity, which resulted in increased carbon isotopic levels of terrestrial fauna and, subsequently, humans. Obviously, even in temperate climatic zones such as the Eurasian Steppe, variation in isotopic values of their inhabitants can be determined not only by diet, but also by environmental factors (e.g. a change in humidity). Failure to take into account such factors may lead to erroneous conclusions on the diet of the populations.

\section{Summary}

One of the most important aspects of modern research in Siberia and the Eurasian Steppe is the necessity of a systematic and well-planned approach to the isotopic analysis, which should include not only the analysis of

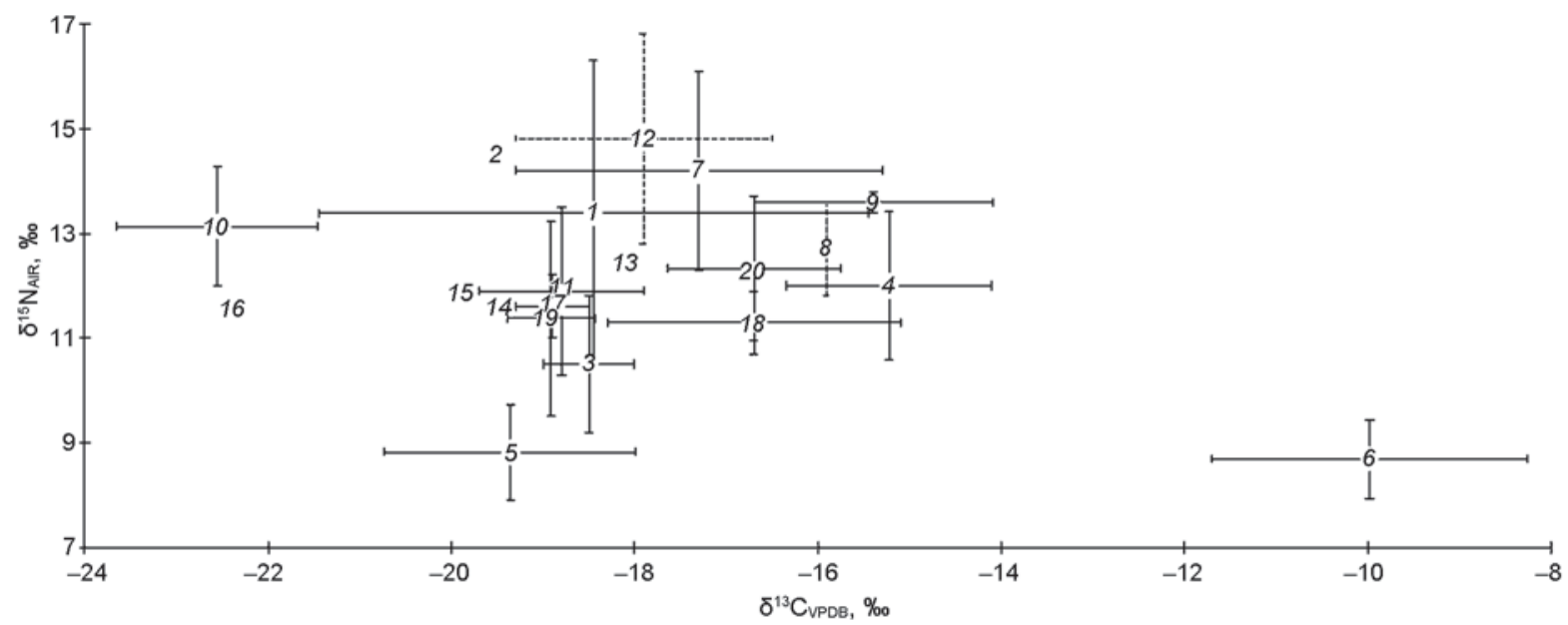

Fig. 2. Isotopic values of the Eurasian Steppe populations (mean values and standard deviations are presented; $n$ is the number of analyzed individuals):

1 - Lake Baikal region, Neolithic-Bronze Age, $n=176$ (Katzenberg, Goriunova, Weber, 2009; Katzenberg et al., 2012; Katzenberg, Weber, 1999); 2 - Baraba forest-steppe, Late Bronze-Early Iron Age, $n=13$ (Privat et al., 2005); 3 - Chelyabinsk Region, Bronze Age, $n=14$ (Privat, 2002); 4 - Minusinsk Basin and Tuva, Early Iron Age, $n=39$ (Murphy et al., 2013); 5 - Northern China, 7000-5800 BC, $n=25$ (Hu, Ambrose, Wang, 2006; Hu et al., 2008); 6- Northern China, 6200-4000 BC, $n=20$ (Pechenkina et al., 2005); 7 - Volga-Don interfluve, Bronze-Early Iron Age, $n=12$ (Iacumin et al., 2004); 8 - North Black Sea region, Early Iron Age, $n=3$ (Ibid.); 9 - Southern Urals, Early Iron Age, $n=2$ (Ibid.); 10 - Dnieper region, Mesolithic-Chalcolithic, $n=28$ (Lillie, Richards, 2000; Lillie, Jacobs, 2006; Lillie, Budd, Potekhina, 2011); 11 - North Caucasus, Chalcolithic-Early Bronze Age, $n=50$ (Hollund et al., 2010); 12 - Northern Caspian region, ChalcolithicBronze Age, $n=78$ (Shishlina et al., 2007, 2009, 2012); 13 - Botai (Kazakhstan), Chalcolithic, $n=1$ (O'Connell, Levine, Hedges, 2003); 14 - Krivoy Rog (Ukraine), Chalcolithic, $n=1$ (Ibid.); 15 - Altai Territory, Early Iron Age, $n=1$ (Ibid.); 16 - Abatsky-3, SW Siberia, Early Iron Age, $n=1$ (Ibid.); 17 - Minusinsk Basin, Chalcolithic-Middle Bronze Age, $n=132$ (Svyatko et al., 2013); 18 - Minusinsk Basin, Late Bronze-Early Iron Age, $n=135$ (Ibid.); 19 - Northern Kazakhstan, Early-Late Bronze Age, $n=55$ (Miller et al., 2014); 20 - Mongolia, Bronze Age-Medieval period, $n=31$ (Fenner, Tumen, Khatanbaatar, 2014). 
humans, but also of all potential components of their diet, such as associated terrestrial and aquatic fauna and plants. It is essential to assess not only dietary changes through time, but also variations in the isotopic baselines of different regions.

In general, the main area of productive paleodietary research in the Eurasian Steppe at the moment is the synthesis of data from different sources (archaeology, isotopic analysis, dental pathology, paleobotany, paleozoology, etc.). With respect to stable isotope analysis, it is important to measure different elements: in addition to nitrogen and carbon isotope analysis, sulfur and hydrogen isotope analysis can provide very detailed data on the diets of ancient populations.

\section{References}

\section{Ambrose S.H. 1993}

Isotopic analysis of palaeodiets: Methodological and interpretive considerations. In Investigations of Ancient Human Tissue: Chemical Analysis in Anthropology. Langhorne: Gordon \& Breach, pp. 59-130.

Bocherens H., Drucker D. 2003

Trophic level isotopic enrichment of carbon and nitrogen in bone collagen: Case studies from recent and ancient terrestrial ecosystems. International Journal of Osteoarchaeology, vol. 13: 46-53.

Bogaard A., Fraser R., Heaton T.H.E.,

Wallace M., Vaiglova P., Charles M., Jones G.,

Evershed R.P., Styring A.K., Andersen N.H.,

Arbogast R.-M., Bartosiewicz L., Gardeisen A.,

Kanstrup M., Maier U., Marinova E., Ninov L.,

Schäfer M., Stephan E. 2013

Crop manuring and intensive land management by Europe's first farmers. PNAS, vol. 110 (31): 12589-12594.

Bogaard A., Heaton T.H.E., Poulton P.,

Merbach I. 2007

The impact of manuring on nitrogen isotope ratios in cereals: archaeological implications for reconstruction of diet and crop management practices. Journal of Archaeological Science, vol. 34: 335-343.

Bronk Ramsey C., Higham T., Bowles A.,

Hedges R. 2004

Improvements to the Pretreatment of Bone at Oxford. Radiocarbon, vol. 46 (1): 155-163.

Brown T.A., Nelson D.E., Vogel J.S.,

Southon J.R. 1988

Improved collagen extraction by modified Longin method. Radiocarbon, vol. 30: 171-177.

\section{Chisholm B.S. 1989}

Variation in diet reconstructions based on stable carbon isotopic evidence. In The Chemistry of Prehistoric Human Bone. Cambridge: Cambridge Univ. Press, pp. 10-37.

Clayton F., Sealy J., Pfeiffer S. 2006

Weaning age among foragers at Matjes river rock shelter, South Africa, from stable nitrogen and carbon isotope analyses. American Journal of Physical Anthropology, vol. 129 (2): 311-317.

\section{DeNiro M.J. 1985}

Postmortem preservation and alteration of in vivo bone collagen isotope ratios in relation to palaeodietary reconstruction. Nature, vol. 317: 806-809.

Fenner J.N., Tumen D., Khatanbaatar D. 2014

Food fit for a Khan: Stable isotope analysis of the elite Mongol Empire cemetery at Tavan Tolgoi, Mongolia. Journal of Archaeological Science, vol. 46: 231-244.

Hedges R.E.M., Clement J.G., Thomas C.D.L.,

O'Connell T.C. 2007

Collagen turnover in the adult femoral mid-shaft: Modeled from anthropogenic radiocarbon tracer measurements. American Journal of Physical Anthropology, vol. 133: 808-816.

Hedges R.E.M., Reynard L.M. 2007

Nitrogen isotopes and the trophic level of humans in archaeology. Journal of Archaeological Science, vol. 34: 12401251.

Hollund H.I., Higham T., Belinskij A.,

Korenevskij S. 2010

Investigation of palaeodiet in the North Caucasus (South Russia) Bronze Age using stable isotope analysis and AMS dating of human and animal bones. Journal of Archaeological Science, vol. 37: 2971-2983.

Hu Y., Ambrose S.H., Wang C. 2006

Stable isotopic analysis of human bones from Jiahu site, Henan, China: implications for the transition to agriculture. Journal of Archaeological Science, vol. 33: 1319-1330.

Hu Y., Wang S., Luan F., Wang C.,

Richards M.P. 2008

Stable isotope analysis of humans from Xiaojingshan site: implications for understanding the origin of millet agriculture in China. Journal of Archaeological Science, vol. 35: 2960-2965.

Iacumin P., Nikolaev V., Genoni L., Ramigni M.,

Ryskov Y.G., Longinelli A. 2004

Stable isotope analyses of mammal skeletal remains of Holocene age from European Russia: A way to trace dietary and environmental changes. Geobios, vol. 37: 37-47.

Jenkins S.G., Partridge S.T., Stephenson T.R.,

Farley S.D., Robbins C.T. 2001

Nitrogen and carbon isotope fractionation between mothers, neonates and nursing offspring. Oecologia, vol. 129: 336-341.

Katzenberg M.A., Goriunova O., Weber A. 2009

Paleodiet reconstruction of Bronze Age Siberians from the mortuary site of Khuzhir-Nuge XIV, Lake Baikal. Journal of Archaeological Science, vol. 36: 663-674.

Katzenberg M.A., McKenzie H.G., Losey R.J.,

Goriunova O.I., Weber A. 2012

Prehistoric dietary adaptations among hunter-fishergatherers from the Little Sea of Lake Baikal, Siberia, Russian Federation. Journal of Archaeological Science, vol. 39: 2612-2626.

Katzenberg M.A., Weber A. 1999

Stable isotope ecology and palaeodiet in the Lake Baikal region of Siberia. Journal of Archaeological Science, vol. 26: 651-659.

Lillie M., Budd C., Potekhina I. 2011

Stable isotope analysis of prehistoric populations from the cemeteries of the Middle and Lower Dnieper Basin, Ukraine. Journal of Archaeological Science, vol. 38: 57-68. 
Lillie M., Jacobs K. 2006

Stable isotope analysis of 14 individuals from the Mesolithic cemetery of Vasilyevka II, Dnieper Rapids region, Ukraine. Journal of Archaeological Science, vol. 33: 880-886.

Lillie M.C., Richards M. 2000

Stable Isotope Analysis and Dental Evidence of Diet at the Mesolithic-Neolithic Transition in Ukraine. Journal of Archaeological Science, vol. 27: 965-972.

Makarewicz C.A. 2014

Winter pasturing practices and variable fodder provisioning detected in nitrogen $\left(\delta^{15} \mathrm{~N}\right)$ and carbon $\left(\delta^{13} \mathrm{C}\right)$ isotopes in sheep dentinal collagen. Journal of Archaeological Science, vol. 41: $502-510$.

Makarewicz C., Tuross N. 2006

Foddering by Mongolian pastoralists is recorded in the stable carbon $\left(\delta^{13} \mathrm{C}\right)$ and nitrogen $\left(\delta^{15} \mathrm{~N}\right)$ isotopes of caprine dentinal collagen. Journal of Archaeological Science, vol. 33: 862-870.

Manolagas S.C. 2000

Birth and death of bone cells: Basic regulatory mechanisms and implications for the pathogenesis and treatment of osteoporosis. Endocrine Reviews, vol. 21: 115-137.

Miller A.V., Usmanova E., Logvin V.,

Kalieva S., Shevnina I., Logvin A., Kolbina A.,

Suslov A., Privat K., Haas K., Rosenmeier M. 2014

Subsistence and social change in Central Eurasia: Stable isotope analysis of populations spanning the Bronze Age transition. Journal of Archaeological Science, vol. 42: 525-538.

Murphy B.P., Bowman D.M.J.S. 2006

Kangaroo metabolism does not cause the relationship between bone collagen $\delta^{15} \mathrm{~N}$ and water availability. Functional Ecology, vol. 20 (6): 1062-1069.

Murphy E.M., Schulting R., Beer N.,

Chistov Y., Kasparov A., Pshenitsyna M. 2013

Iron age pastoral nomadism and agriculture in the eastern Eurasian steppe: Implications from dental palaeopathology and stable carbon and nitrogen isotopes. Journal of Archaeological Science, vol. 40: 2547-2560.

O’Connell T.C., Kneale C.J., Tasevska N.,

Kuhnle G.G.C. 2012

The diet-body offset in human nitrogen isotopic values: A controlled dietary study. American Journal of Physical Anthropology, vol. 149: 426-434.

O'Connell T.C., Levine M.A., Hedges R.E.M. 2003

The importance of fish in the diet of central Eurasian peoples from the Mesolithic to the Early Iron Age. In Prehistoric Steppe Adaptation and the Horse. Cambridge: Cambridge Univ. Press, pp. 253-268.

Parfitt A.M. 1994

Osteonal and hemi-osteonal remodeling: The spatial and temporal framework for signal traffic in adult human bone. Journal of Cellular Biochemistry, vol. 55: 273-286.

Pechenkina E.A., Ambrose S.H., Xiaolin M.,

Benfer J.R.A. 2005

Reconstructing northern Chinese Neolithic subsistence practices by isotopic analysis. Journal of Archaeological Science, vol. 32: 1176-1189.

Pechenkina E.A., Benfer R.A. Jr., Xiaolin M. 2007

Diet and health in the Neolithic of the Wei and middle Yellow River basins, Northern China. In Ancient Health:
Skeletal Indicators of Agricultural and Economic Intensification. Gainesville: Univ. of Florida Press, pp. 255-272.

Pechenkina E.A., Benfer R.A., Zhijun W. 2002

Diet and health changes at the end of the Chinese neolithic: The Yangshao/Longshan transition in Shaanxi province. American Journal of Physical Anthropology, vol. 117 (1): 15-86.

Privat K. 2002

Preliminary report of palaeodietary analysis of human and faunal remains from Bolshekaragansky Kurgan 25. In Arkaim: Nekropol (po materialam kurgana Bolshekaraganskogo mogilnika). Chelyabinsk: Ural. Kn. Izd., pp. 166-171.

Privat K.L., O'Connell T.C., Hedges R.E.M. 2007

The distinction between freshwater- and terrestrial-based diets: Methodological concerns and archaeological applications of sulphur stable isotope analysis. Journal of Archaeological Science, vol. 34: 1197-1204.

Privat K.L., Schneeweiss J., Benecke N.,

Vasiliev S.K., O'Connell T.C., Hedges R.E.M., Craig O. 2005

Economy and diet at the Late Bronze Age/Iron Age site of Chicha: Artefactual, archaeozoological and biochemical analyses. Eurasia Antiqua, vol. 11: 419-448.

Pyankov V.I., Gunin P.D., Tsoog S., Black C.C. 2000

C4 plants in the vegetation of Mongolia: Their natural occurrence and geographical distribution in relation to climate. Oecologia, vol. 123: 15-31.

Reynard L.M., Hedges R.E.M. 2008

Stable hydrogen isotopes of bone collagen in palaeodietary and palaeoenvironmental reconstruction. Journal of Archaeological Science, vol. 35: 1934-1942.

Richards M.P., Fuller B.T., Sponheimer M.,

Robinson T., Ayliffe L. 2003

Sulphur isotopes in palaeodietary studies: A review and results from a controlled feeding experiment. International Journal of Osteoarchaeology, vol. 13: 37-45.

Richards M.P., Schulting R.J., Hedges R.E.M. 2003

Sharp shift in diet at onset of Neolithic. Nature, vol. 425: 366.

Schoeninger M.J. 1985

Trophic level effects on ${ }^{15} \mathrm{~N} /{ }^{14} \mathrm{~N}$ and ${ }^{13} \mathrm{C} /{ }^{12} \mathrm{C}$ ratios in bone collagen and strontium levels in bone mineral. Journal of Human Evolution, vol. 14: 515-525.

Schoeninger M.J. 2009

Stable isotope evidence for the adoption of maize agriculture. Current Anthropology, vol. 50 (5): 633-640.

Shishlina N.I., van der Plicht J., Hedges R.E.M., Zazovskaya E.P., Sevastyanov V.S.,

Chichagova O.A. 2007

The Catacomb cultures of the north-west Caspian steppe: ${ }^{14} \mathrm{C}$ chronology, reservoir effect, and palaeodiet. Radiocarbon, vol. 49: 713-726.

Shishlina N.I., Zazovskaya E.P., van der Plicht J., Hedges R.E.M., Sevastyanov V.S., Chichagova O.A. 2009

Paleoecology, subsistence, and ${ }^{14} \mathrm{C}$ chronology of the Eurasian Caspian Steppe Bronze Age. Radiocarbon, vol. 51: 481-499.

Shishlina N., Zazovskaya E., van der Plicht J., Sevastyanov E.V. 2012

Isotopes, plants, and reservoir effects: Case study from the Caspian Steppe Bronze Age. Radiocarbon, vol. 54: 749-760. 
Svyatko S.V., Schulting R.J., Mallory J.,

Murphy E.M., Reimer P.J., Khartanovich V.I.,

Chistov Y.K., Sablin M.V. 2013

Stable isotope dietary analysis of prehistoric populations from the Minusinsk Basin, Southern Siberia, Russia: A new chronological framework for the introduction of millet to the eastern Eurasian steppe. Journal of Archaeological Science, vol. 40: 3936-3945.

Tieszen L.L., Fagre T. 1993

Carbon isotopic variability in modern and archaeological maize. Journal of Archaeological Science, vol. 20: 25-40.

Turner B.L., Zuckerman M.K., Garofalo E.M.,

Wilson A., Kamenov G.D., Hunt D.R.,

Amgalantugs T., Frohlich B. 2012

Diet and death in times of war: Isotopic and osteological analysis of mummified human remains from southern Mongolia. Journal of Archaeological Science, vol. 39: 3125-3140.

\section{Van der Merwe N.J., Medina E. 1991}

The canopy effect, carbon isotope ratios and foodwebs in Amazonia. Journal of Archaeological Science, vol. 18: 249-259.

Van Klinken G.J. 1999

Bone collagen quality indicators for palaeodietary and radiocarbon measurements. Journal of Archaeological Science, vol. 26: 687-695.
Wang G., Han J., Zhou L., Xiong X., Wu Z. 2005

Carbon isotope ratios of plants and occurrences of $\mathrm{C} 4$ species under different soil moisture regimes in arid region of Northwest China. Physiologia Plantarum, vol. 125 (1): 74-81.

\section{Wang R.Z. 2004}

Photosynthetic pathways and life form types for native plant species from Hulunbeier Rangelands, Inner Mongolia, North China. Photosynthetica, vol. 42: 219-227.

Wang R.Z. 2005

$\mathrm{C} 3$ and $\mathrm{C} 4$ photosynthetic pathways and life form types for native species from agro-forestry region, Northeastern China. Photosynthetica, vol. 43: 535-549.

Wild E.M., Arlamovsky K.A., Golser R.,

Kutschera W., Priller A., Puchegger S., Rom W.,

Steier P., Vycudilik W. 2000

${ }^{14} \mathrm{C}$ dating with the bomb peak: An application to forensic medicine. Nuclear Instruments and Methods in Physics Research Section B: Beam Interactions with Materials and Atoms, vol. 172: 944-950. 